\title{
FIRST RECORDS OF THE LAND SNAIL MONACHA FRUTICOLA (GASTROPODA, STYLOMMATOPHORA, HYGROMIIDAE) IN WESTERN UKRAINE
}

\author{
N. V. Gural-Sverlova*, R. I. Gural \\ State Museum of Natural History, NAS of Ukraine \\ Teatralna Str., 18, Lviv, 79008 Ukraine \\ E-mail: sverlova@pip-mollusca.org \\ ${ }^{*}$ Corresponding author
}

\begin{abstract}
First Records of the Land Snail Monacha fruticola (Gastropoda, Stylommatophora, Hygromiidae) in Western Ukraine. Gural-Sverlova, N. V., Gural, R. I. - Two colonies of the land snail Monacha fruticola, whose native range is considered limited by the Crimea, were first discovered in Western Ukraine, in Lviv City and in its immediate vicinity (Bryukhovichi settlement). They are the northernmost records of this species, currently known. The present distribution of $M$. fruticola outside the Crimean peninsula is analyzed.

Key words: terrestrial mollusks, anthropochory, invasive species, Ukraine.
\end{abstract}

\section{Introduction}

The native range of Monacha fruticola (Krynicki, 1833) is probably limited by the Crimean peninsula. Previously, Asia Minor was also considered part of it (Schileyko, 1978). However, Hausdorf (2000) has showed that other species of Monacha Fitzinger, 1833 are distributed there. Known records of $M$. fruticola in southern Ukraine outside the Crimean peninsula (Schileyko, 1978; Korniushin, 1986; Kramarenko \& Sverlova, 2001; Sverlova, 2006; Ryabseva, 2012; Gural-Sverlova et al., 2012; Balashov et al., 2013; Gural-Sverlova et al., 2018) are usually considered solely the result of anthropochory (Schileyko, 1978). Recently, a case of the introduction of this species by the human into Armenia was also described (Gural-Sverlova et al., 2017).

\section{Material and methods}

In 2018-2019, two colonies of M. fruticola were discovered and investigated in Western Ukraine, the localities of which and the dates of collection are indicated below.

1) Lviv Region, Lviv City, Sykhiv microdistrict, Chervonoi Kalyny avenue, a low slope on the southern side of the house number 123 and partly on the western side of the house number 121 adjacent to it [49.782846 $\mathrm{N} 24.060753 \mathrm{E}]$. The vegetation is mosaic: flower beds and open areas overgrown with grass alternate with dense groups of shrubs and young trees (fig. 1, A), as well as with fragments of hedges. The length of the area inhabited by molluscs is about $100 \mathrm{~m}$. The colony was first found by V. B. Rizun on 12.05 .2019 , examined by us on 25.05.2019, and again on 4.08.2019.

2) Lviv Region, territory subordinate to the Lviv City council, Briukhovychi settlement, Lvivska street, between the houses (mansions) number 28 and 32 [49.905031 N 23.960935 E], household plots. The vegetation is mosaic: ornamental and berry shrubs, young trees, flower beds, thickets of weed grass, etc. Mollusks were collected along the fences, on a site about $40 \mathrm{~m}$ long. The colony was first discovered by N. V. Gural-Sverlova on 1.11.2018, and re-examined on 31.07.2019. 
Mollusks were collected after rains on plants, soil surface or fences, then fixed, dissected and identified by standard methods (Schileyko, 1978). For the identification, both conchological and anatomical (structure of the distal parts of the reproductive system) characters were used. The shell width was measured with an accuracy of $0.1 \mathrm{~mm}$ with a caliper; if the size was less than $10 \mathrm{~mm}$, an eyepiece micrometer and a stereoscopic microscope MBS- 9 were used. The number of adult snails in the samples (table 1) was determined by the completed growth of the shell, the even and thickened edges of the aperture, and the presence of a roller-like thickening inside the aperture - the lip.

The studied conchological materials were deposited in the malacological collection of the State Museum of Natural History of the National Academy of Sciences of Ukraine in Lviv.

\section{Results and discussion}

The conchological and anatomical (structure of genitalia) features of the adult molluscs collected in Western Ukraine coincide with the available descriptions and images of M. fruticola from different parts of the present range of this species (Schileyko, 1978; Balashov, 2016; Gural-Sverlova et al., 2017). The shell is depressed, monochromatic, light corneous; a spotted mantle often shines through it in live snails (fig. 1, B, C). The umbilicus is narrow, partially covered with reflexed columellar margin of the aperture. In adult individuals, the margins of the aperture are light, in contrast to Monacha cartusiana (O.F. Müller, 1774), which quickly spreads now across Western Ukraine. The shell surface is with small radial wrinkles. Numerous randomly located small dents are usually clearly visible at the ultimate and penultimate whorl. At a 20 -fold (and sometimes even 10-fold) magnification, fragments of thin and densely arranged spiral lines are also visible on the shell surface, which we previously noted in the specimens of $M$. fruticola from the mountainous Crimea and Armenia (Gural-Sverlova et al., 2017). The structure of the reproductive system of $M$. fruticola from Western Ukraine is fully consistent with the description and image given in the monograph by Schileyko (1978). All dissected specimens from Lviv and Briukhovychi had a long thin flagellum, the length of which slightly exceeded the length of the epiphallus. This peculiarity clearly distinguishes $M$. fruticola from other species of the subgenus Paratheba Hesse, 1914, distributed in Asia Minor and described in Hausdorf (2000).

According to literature data, the shell width in adults of $M$. fruticola varies from 14 to $20 \mathrm{~mm}$ (Schileiko, 1978). In the introduced colony of this species previously investigated by us in Armenia, the shell sizes were slightly smaller - from 13.3 to $18.5 \mathrm{~mm}$ (Gural-Sverlova et al., 2017). Similar results were obtained for Western Ukraine (table 1), where the width of the measured shells in adults varied from 14.2 to $18.1 \mathrm{~mm}$. It is not known whether this is a result of the negative influence of the climatic conditions of the regions far remote from the native range of $M$. fruticola, or the individuals with larger shells are relatively rare in colonies of this species and therefore accidentally did not fall into the studied samples.

Table 1. Shell width in samples of M. fruticola from Western Ukraine, $\mathrm{mm}$

\begin{tabular}{|c|c|c|c|c|c|c|c|}
\hline \multicolumn{4}{|c|}{ Adults } & \multicolumn{4}{|c|}{ Immature specimens } \\
\hline $\mathrm{N}$ & $\min$ & $\max$ & $\mathrm{M} \pm \mathrm{m}$ & $\mathrm{N}$ & $\min$ & $\max$ & $\mathrm{M} \pm \mathrm{m}$ \\
\hline \multicolumn{8}{|c|}{ Briukhovychi, 1.11.2018 } \\
\hline- & - & - & - & 13 & 9.2 & 13.1 & $11.1 \pm 0.3$ \\
\hline \multicolumn{8}{|c|}{ Briukhovychi, 31.07.2019 } \\
\hline 7 & 14.2 & 16.7 & $15.5 \pm 0.3$ & 1 & - & - & 12.8 \\
\hline \multicolumn{8}{|c|}{ Lviv, 25.05.2018 } \\
\hline 4 & 15.8 & 18.1 & $17.2 \pm 0.5$ & 40 & 5.8 & 16.7 & $13.2 \pm 0.4$ \\
\hline \multicolumn{8}{|c|}{ Lviv, 4.08.2018 } \\
\hline $22^{*}$ & 14.7 & 17.7 & $16.2 \pm 0.2$ & 15 & 4.1 & 15.5 & $11.4 \pm 0.8$ \\
\hline
\end{tabular}

Notes. $M$ - arithmetic mean; $\mathrm{m}$ - its error; max — the maximum value of the parameter; min — the minimum value of the parameter; ${ }^{*}$ one shell that received significant mechanical damage during growth was not measured. 


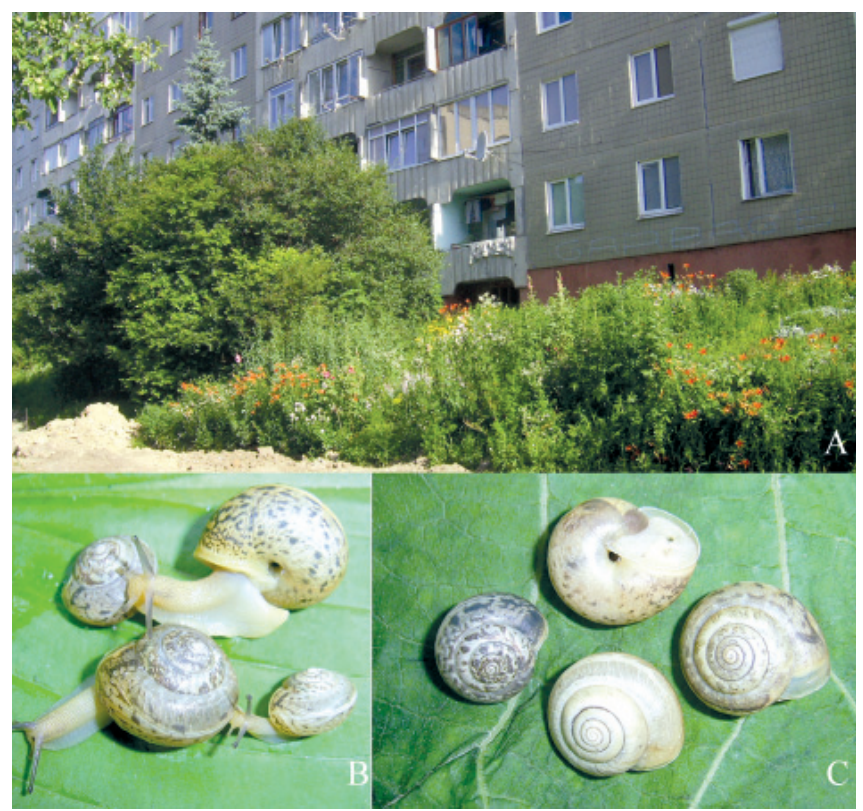

Fig. 1. Habitat of M. fruticola and snails of different ages: A, B - Lviv; C - Briukhovychi.

The life cycle and seasonal dynamics of the size and age structure of the colonies of $M$. fruticola have not been specifically studied both in the native range of this species and beyond. According to our observations in the mountainous Crimea (in Bakhchysarai in 2010-2011), in the continental part of the steppe zone of Ukraine (in Kherson in 2005) and in Armenia (Gural-Sverlova et al., 2017), immature individuals predominate in the colonies of $M$. fruticola in May. Adult mollusks at this time are relatively rare; obviously, all of them are represented by individuals that have recently completed their growth (GuralSverlova et al., 2017). A similar pattern was observed by us at the end of May 2019 in Lviv (table 1); the collected sample consisted mainly of the immature snails of different sizes (fig. 1, B). By early August, the number of adults increased significantly (table 1), in addi-

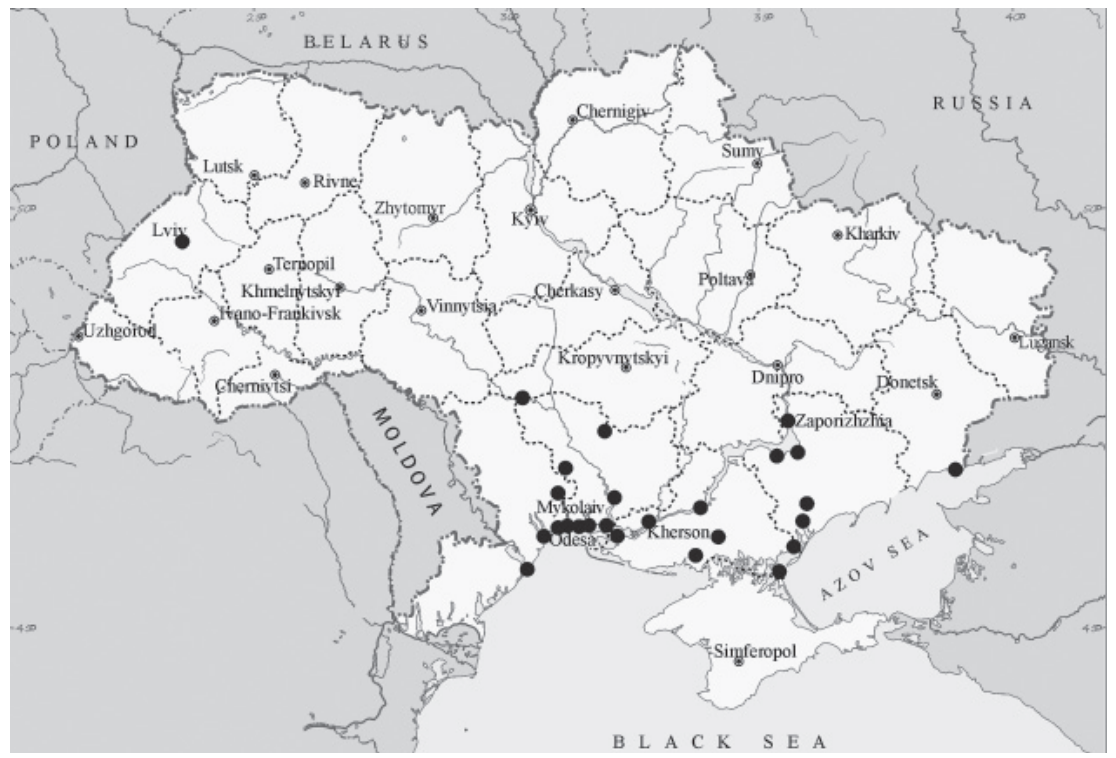

Fig. 2. Known records of $M$. fruticola in Ukraine outside the Crimea. 
tion, one copulating pair was found. A small sample from Briukhovychi collected at the beginning of November in 2018 consisted exclusively of immature snails whose shell width did not exceed $13.1 \mathrm{~mm}$ (table 1). In the second half of summer, adults predominated in the studied site (fig. 1, C), as in Lviv. Obviously, in Western Ukraine, most individuals of $M$. fruticola reach maturity and begin to breed in the second half of summer. The known finds of $M$. fruticola outside the Crimean peninsula have so far been limited to the steppe zone of Ukraine (fig. 2) and to one introduced colony in Armenia, discovered in 2016 in summer cottages not far from Yerevan (Gural-Sverlova et al., 2017).

In the continental part of the steppe zone of Ukraine, the colonies of $M$. fruticola are found mainly along the sea coast, along the banks of estuaries, reservoirs and large rivers (fig. 2). A similar distribution pattern in Ukraine is also demonstrated by another representative of the family Hygromiidae - Xeropicta krynickii (Krynickii, 1833), whose range is gradually expanding as a result of anthropochory (Gural-Sverlova \& Gural, 2017). Near the colonies of $M$. fruticola found in Western Ukraine, such large bodies of water that can significantly affect the climatic conditions of the mollusk habitats are absent, although there are several small ponds near the colony in Briukhovychi. Obviously, in both cases, the unintentional introduction of mollusks occurred along with cultivated plants.

\section{Conclusions}

The described records of $M$. fruticola in Lviv and its environs are the most northern and at the same time the most western of all currently known localities of this species. The size of the areas inhabited by mollusks, especially in Lviv, the re-detection of individuals of $M$. fruticola after the winter of 2018-2019 in Briukhovychi, the presence of the mollusks of different ages in the samples suggest that this species was able to successfully adapt to living in urban areas of Western Ukraine. In the future, the further spreading of $M$. fruticola can be expected in similar habitats of this region.

The authors are grateful to V. B. Rizun (State Museum of Natural History, Lviv) for information on the location of the colony of M. fruticola discovered by him in Lviv, as well as A. N. Shklyaruk (Odesa), S. S. Kramarenko (Mykolayiv National Agrarian University), V. A. Busel (National Natural Park «Velykyi Luh», Zaporizhzhia Region) and other persons, who at different times transferred the materials they collected to the malacological collection of SMNH.

\section{References}

Balashov, I. A. 2016. Stylommatophora. Naukova dumka, Kiev, 1-591 (Fauna Ukrainy. Vol. 29, is. 5) [In Russian].

Balashov, I. A., Kramarenko, S. S., Zhukov, A.V., Shklyaruk, A. N., Baidashnikov, A. A., Vasyliuk, A. V. 2013. Contribution to the knowledge of terrestrial molluscs in southeastern Ukraine. Malacologia Bohemoslovaca, 12, 62-69.

Gural-Sverlova, N. V., Amiryan, A. L., Gural, R. I. 2017. Addition to the studies of land molluscs of Armenia. Ruthenica, Russian Malacological Journal, 27 (2), 87-93 [In Russian].

Gural-Sverlova, N. V., Busel, V. A., Gural, R. I. 2018. Species composition of land molluscs of Zaporozhye region and anthropochory influence on it. Ruthenica, Russian Malacological Journal, 28 (3), 101-112 [In Russian].

Gural-Sverlova, N. V., Gural, R. I. 2012. Malacological Collections. Lviv, 1-253 (Naukovi Kolektsii Derzhavnoho Pryrodoznavchoho Muzeiu. Vol. 4) [In Ukrainian].

Gural-Sverlova, N. V., Gural, R. I. 2017. Expansion of the ranges of land mollusks of the genus Xeropicta (Gastropoda, Hygromiidae) in Ukraine. Russian Journal of Biological Invasions, 8 (3), 212-217.

Kramarenko, S. S., Sverlova, N. V. 2001. Terrestrial malakofauna (Gastropoda, Pulmonata) of Mykolaiv Region. Vestnik Zoologii, 35 (2), 75-78 [In Russian].

Korniushin, A. V. 1986. Land molluscs (Gastropoda, Pulmonata) in the arboretum Askania-Nova. Vestnik Zoologii, 1, 41 [In Russian].

Ryabseva, Yu. S. 2012. New data on the distribution and reproduction of terrestrial gastropod Monacha fruticola (Gastropoda, Pulmonata, Hygromiidae) under laboratory conditions. Vestnik Zoologii, 46 (2), 155-160 [In Russian].

Sverlova, N. V. 2006. On the distribution of some species of land molluscs on the territory of Ukraine. $R u$ thenica, Russian Malacological Journal, 16 (1-2), 119-139 [In Russian].

Schileyko A. A. 1978. Land molluscs of the superfamily Helicoidea. Nauka, Leningrad, 1-384 (Fauna SSSR. Vol. 3, is. 6) [In Russian].

Hausdorf, B. 2000. The genus Monacha in Turkey (Gastropoda: Pulmonata: Hygromiidae). Archiv für Molluskenkunde, $128(1 / 2), 61-151$.

Received 12 November 2019

Accepted 25 February 2020 